\title{
Kernos
}

Revue internationale et pluridisciplinaire de religion grecque antique

1 | 1988

Varia

\section{The Idaean Cave. Minoan and Greek Worship}

\section{J.A. Sakellarakis}

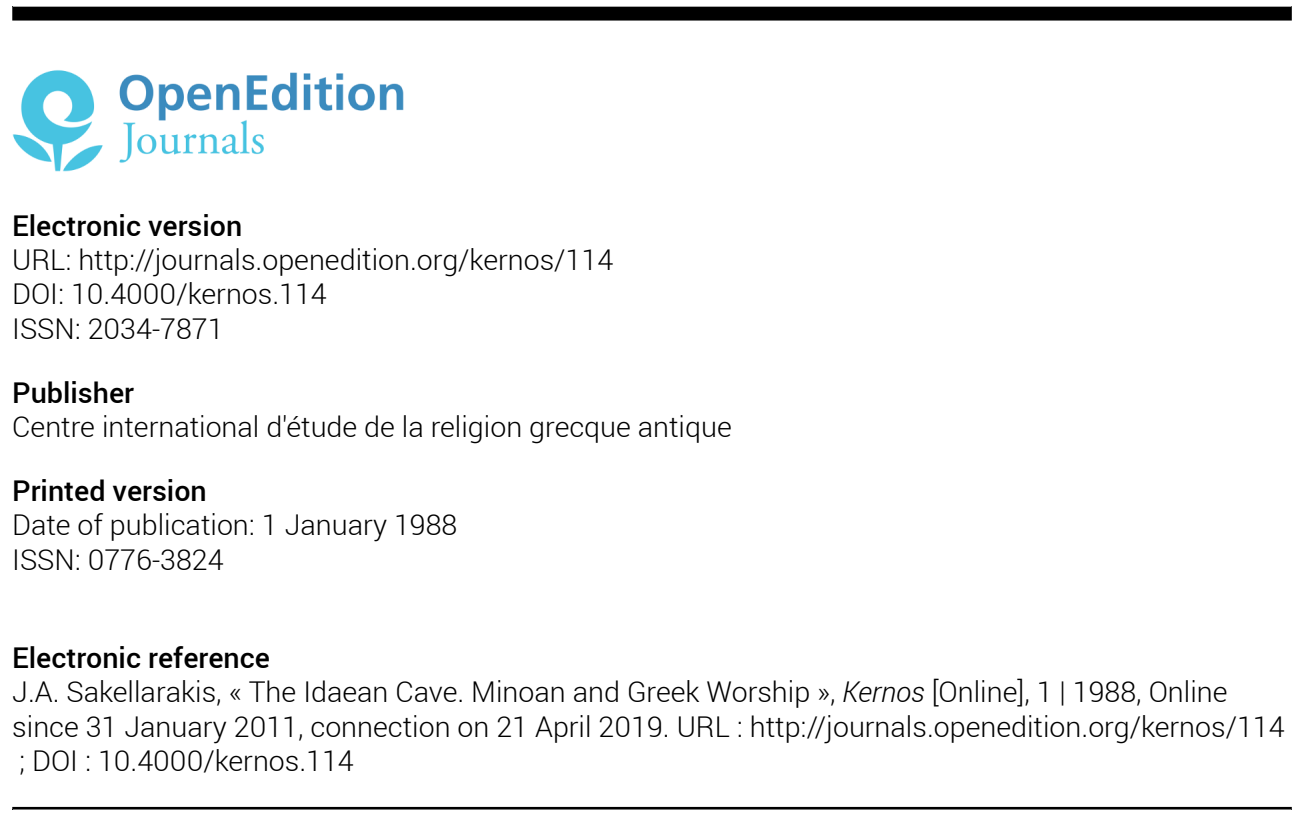

Kernos 
Kernos, 1(1988), p. 207-214.

\section{THE IDAEAN CAVE. MINOAN AND GREEK WORSHIP}

I am particularly delighted about today's interdisciplinary conference of ancient Greek religion which is convened by the recently established Centre for the Study of Ancient Greek Religion. At the opening of the colloquium this morning, eminent speakers emphasized how these studies have been delayed until now, their importance following the foundation of the centre and still further the necessity of interdisciplinary research. This last point is the most important since the study of ancient Greek religion cannot and must not be the concern solely of those who study religion. On the contrary, it is a fundamental work of historians, philologists, even art historians and certainly of archaeologists. I shall endeavour to demonstrate the necessity and also the importance of an interdisciplinary approach in the study of ancient Greek religion by selecting an example, one only, of an important Greek sanctuary, namely, the Idaean Cave.

The new investigation of the Idaean $\mathrm{Cave}^{1}$ (fig. 1) which has been resumed by the Archaeological Society of Athens is known as much from publications as from different communications, so that it

1 To date, the following articles have been published concerning the new exca-

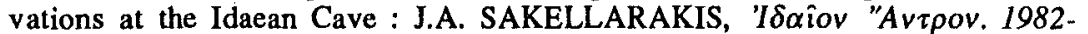

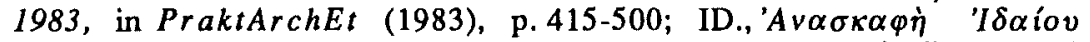

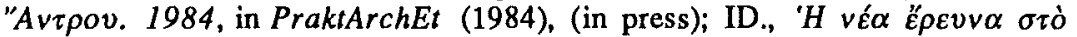

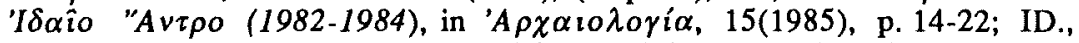
L'Antro Ideo. Cento Anni di Attività Archéologica, in Atti dei Convegni Lincei 74, Centi Anni di Attività Archéologica Italiana in Creta, Roma 1985,

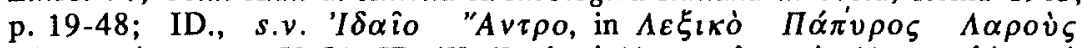

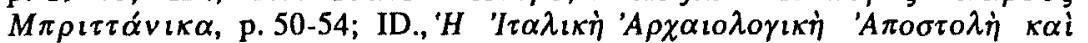

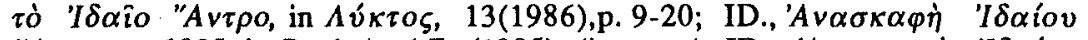

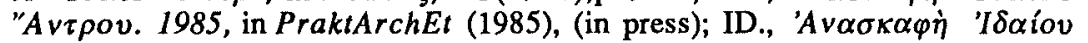
"Avipov. 1986, in PraktArchEt, (1986), (in press); ID., Some Geometric and Archaic Finds from the Idaean Cave, in R. HÄGG - N. MARINATOS ed., Early Greek Cult Practice (in press); ID., Antro Ideo, in Enciclopedia Italiana

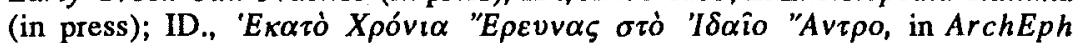

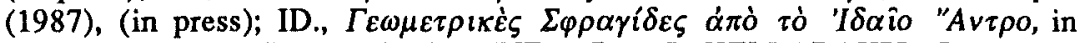
ArchEph (1988), (in press); G. SINES - J.A. SAKELLARAKIS, Lenses in Antiquity, in $A J A, 91(1987)$, p. 191 sq. 


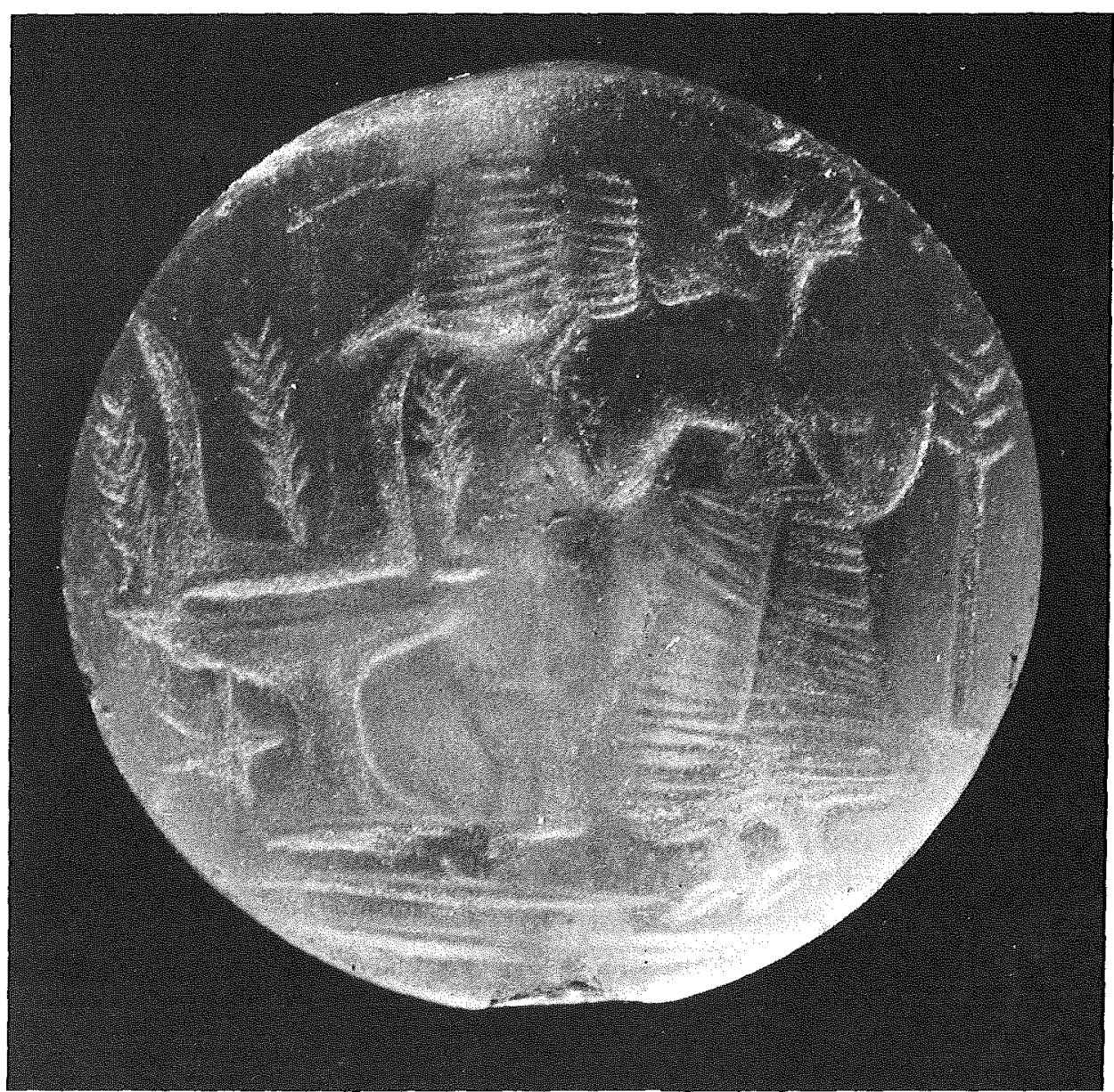

Fig. 3. Seal of rock crystal

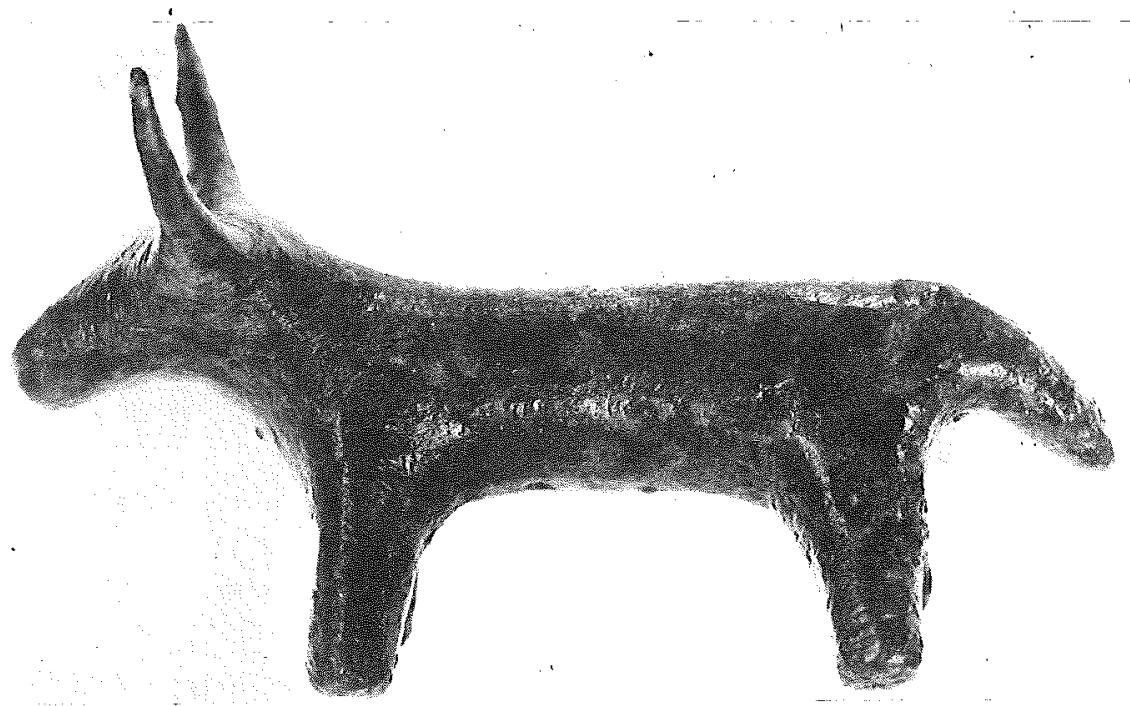

Fig. 4. Bronze bull figurine 


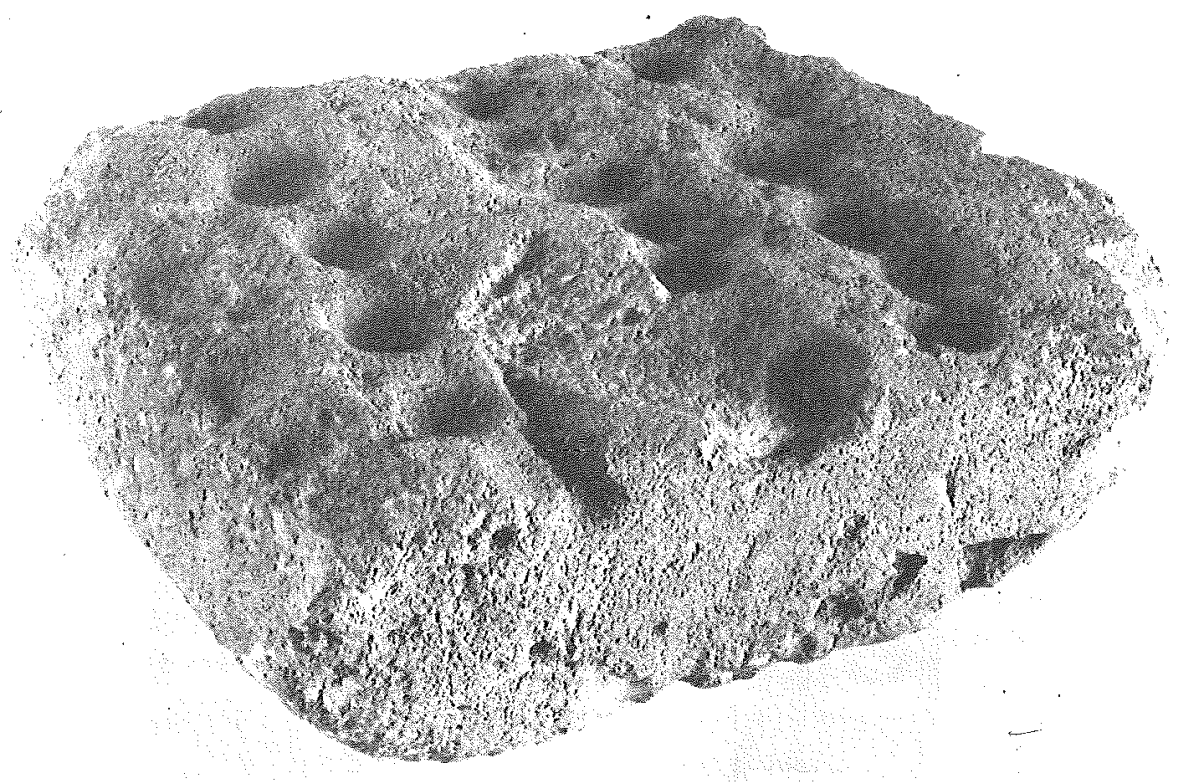

Fig. 5. Stone kernos

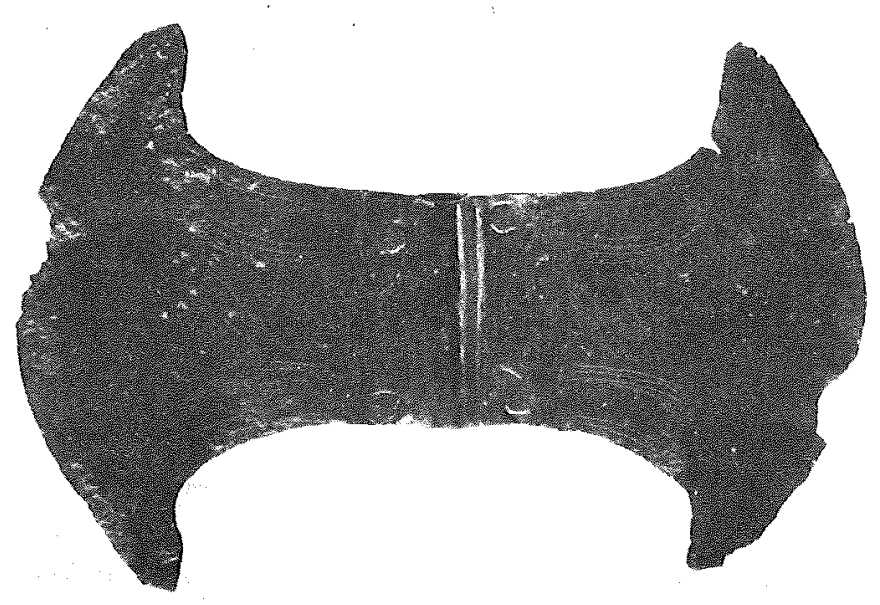

Fig. 6. Bronze double axe 
Very many of the finds from the new excavations are remarkable not only as works of art, as was usually the case with the older finds, but also for the evidence they provide for worship. For example, the enormous number of worked ivory objects which were imported from north Syria and Palestine in the 8th cent. B.C. ${ }^{11}$, which are not of importance only for the history of art and as imports, for the commerce of the period. It is certain that many of them adorned furniture, and thus cannot but bring to mind the ancient testimony for the existence of the throne of Zeus in the Idaean Cave, $\kappa \alpha \tau^{\prime}$ "̈ $\tau o \varsigma \sigma \tau o \rho v v \mu \varepsilon ́ v o v^{12}$, an essential element of the worship, as is reported concerning the descent of Pythagoras into the Idaean Cave. Furthermore, certain other dedications, made from precious materials and of the highest quality of execution, indicate through the subject matter with which they are decorated, that during certain periods, Cretan aristocrats ascended to the Idaean Cave as worshippers ${ }^{13}$. Equipment discovered for the first time shows the practice of a singular form of worship and different vases indicate that they contained liquid or solid offerings. Sacrifices are confirmed by the number of bones of different animals which have been recovered and studied for the first time.

Apart from the existence, outside the cave, of a vast altar cut in the rock, it is certain that sacrifices took place even inside. It is not only the animal bones mentioned above, but also the jet black, oily earth ${ }^{14}$ in which they came to light. In the cave itself, there were different structures, a wall built roughly in the middle 15 . It is most probable that in other structures, once more related to worship or even the activities of the faithful, bricks were used which have been found in certain parts of the cave in significant quantities. Ash altars of different periods have been noted, once more at different points

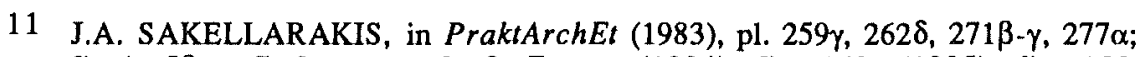
fig.4, $5 \beta-\gamma, 7,8 \mathrm{a}-\sigma \tau, \eta, 9-10$; Ergon (1984), fig. 149; (1985), fig. 109; (1986), fig. 137. Compare R. BARNETT, A Catalogue of the Nimrud lvories, London, 1975.

12 PORPH., Vit. Pyth., 17.

13 J.A. SAKELLARAKIS, Geometric and Archaic Finds from the Idaean Cave, in R. HÄGG - N. MARINATOS ed., Early Greek Cult Practice (in press).

14 Cf. J.A. SAKELLARAKIS, PraktArchEt (1983-1986), passim.

15 J.A. SAKELLARAKIS, in PraktArchEt (1986), (in press); in Ergon (1986), fig. 126-127. 
on the edges of the cave or in cavities, in one instance associated with paving ${ }^{16}$.

Finally, many finds and even observations made during excavation confirm evidence known from philological and epigraphic sources for Greek worship in the Idaean Cave. The discovery of a bronze shield of the 6 th cent. B.C. in a 1 st cent. B.C. level 17 demonstrated not only the long period of time dedications were exhibited, but still more the way in which some of these objects were dedicated. This is because the shield most probably had been hung

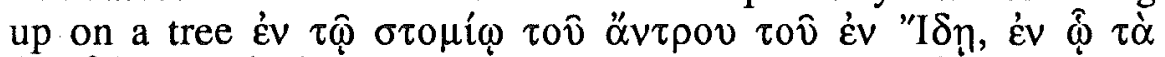

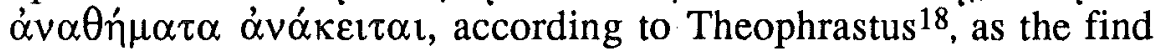
spot in the excavation illustrates. The offerings of Cretan cities at the Idaean Cave were not confined only to the three yearly sacrifices of Gortys and of its vassals according to one inscription ${ }^{19}$. Furthermore, in the 1 st cent. B.C. or the 1 st cent. A.D., Polyrrenia dedicated a stater in mint condition of Alexander the Great which was struck in Babylon in 332 B.C. ${ }^{20}$

Thus, the new excavations of the Archaeological Society of Athens provided important new evidence concerning Greek worship in the cave. Nevertheless, the new finds are yet more significant on the religious side since they attest, for the first time, prior Minoan worship in the Idaean Cave. Minoan worship was unknown until now, no matter how much researchers connected, as we shall see, Cretan Zeus with the Minoan god of vegetation. It is curious, in this respect, that the more diligent scholars overlooked two important finds from the 1885 excavations. A bronze statuette of a worship$\operatorname{per}^{21}$ (fig. 2) and the seal of rock crystal, very well known compared to the others, with a representation of a female figure blowing

16 For Cavity b, cf. J.A. SAKELLARAKIS, in PraktArchEt (1984), (in press).

17 J.A. SAKELLARAKIS, in PraktArchEt (1984), (in press); in Ergon (1984), fig. 146.

18 THEOPHR., Hist. Plant., 3, 3, 4.

19 IC, IV, 80 and 146.

20 J.A. SAKELLARAKIS, in PraktArchEt (1984), (in press); in Ergon (1984), fig. 152.

21 MARIANI, in MA, 5(1895), p. 178, n. 4; Efi SAPOUNA-SAKELLARAKIS, Die minoische, bronzene menschliche Idole (PBF), (in press). 
on a triton shell22 (fig. 3), in front of a biconcave altar with Horns of Consecration and branches. This important scene has never been given the attention it deserves for Minoan cult in the Idaean Cave, even if the provenance of the seal as a chance find from the cave was known.

Minoan presence in the Idaean Cave has been confirmed by the new excavations as early as in the Early Minoan Period with notable examples of pottery and other objects ${ }^{23}$. In the Middle Minoan Period, apart from pottery there are certain important seals ${ }^{24}$. To the beginning of the Late Minoan Period date the first certain excavated evidence for worship in the Idaean Cave, dedications and equipment characteristic of worship, a bronze bull figurine 25 (fig. 4), a stone $\operatorname{kernos}^{26}$ (fig. 5), and a bronze double axe ${ }^{27}$ (fig. 6). The worship of a Minoan deity in the Idaean Cave is certain.

As has been noted, scholars have already hypothesised that the origin of the singular worship of Cretan Zeus, the god who was born and died every year, lies in the prehistoric, Minoan deity, the young god who personified the yearly birth and death of the vegetation cycle, despite the lack of archaeological proof. This evidence is now explicit and unquestionable, and furthermore indicates the

$22 C M S, I I 3, \mathrm{n}^{\circ}$ 7. To the already rich bibliography there should be added G. KARO, in $A f R W, 7(1904)$, p. 138; R. DUSSAUD, Les Civilisations Préhelléniques, Paris, 1914, fig. 252; R. VALLOIS, in REA, 32(1930), p. 101, fig. 1; J. BOARDMAN, The Cretan Collection in Oxford, Oxford, 1961, p. 78, n. 2; K. MAJEWSKI, Kreta, Hellada, Cyklady, Warsaw, 1963, p. 189, fig. 118; P. FAURE, Fonctions des Cavernes Crétoises, Paris, 1964, p. 105, 106 n. 6, 116 n. 2, 125 n. 1; E. BRANDT, Gruss und Gebet, Waldsassen, 1965, 1 sq.; L. PRESS, Architecture in Pre-Greek Iconography, Vroclav, 1967 , p. 240, $\mathrm{n}^{\circ} 16$; L. PRESS, in Atti $e$ Memorie del $1^{\circ}$ Congresso Internazionale di Micenologia, Rome, 1967, p. 161; J.A. SAKELLARAKIS in U. JANTZEN, Neue Forschungen in Griechischen Heiligtümern, Tübingen, 1976, p. 306; C. BAURAIN - P. DARCQUE, in $B C H, 107(1983)$, p. 54-55, fig. 35; H. VERBRUGGEN, Le Zeus Crétois, Paris, 1981, p. 74, n. 23.

23 J.A. SAKELLARAKIS, in PraktArchEt (1983), pl. 276a, $\gamma$; ID., in PraktArchEt (1985), (1987), (in press); in Ergon (1985), fig. 106; (1987), fig. 132.

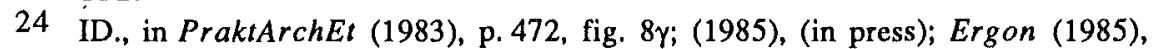
fig. 100-101.

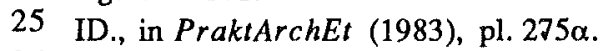

26 ID., in PraktArchEt (1984), (in press).

27 ID., in PraktArchEt (1985), (in press); in Ergon (1985), fig. 102-103. 
extent and dynamism of Minoan worship which preceded. And with the Idaean Cave and Minoan worship must be linked the remarkable Late Minoan building at Zominthos ${ }^{28}$, erected at height of $1200 \mathrm{~m}$, on Psiloritis, precisely on a main route to the cave.

From the manifold finds of the new investigation of the Idaean Cave, it can be concluded that the sequence from Minoan to Greek worship was unbroken. Evidence for Mycenaean, that is to say the more ancient Greek, worship is strong. The Idaean Cave went on to be a most important shrine, which received a great number of pilgrims. The offerings of these times are characteristically great in number, such as clay statuettes, often large ${ }^{29}$. They are joined for the first time by iconographic representations, such as large painted terracotta Horns of Consecration with holes, most probably for attaching banches and shafts of Double Axes (fig. 7). In this period, one must concentrate investigation more intensively on verifying continuity of worship of which the Idaean Cave constitutes a leading example.

However, as has been noted above with regard to more general religious study and certainly the study of continuity of worship from the prehistoric period to historic times, multidisciplinary research is absolutely essential. The study of diachronic worship presupposes the abandonment of entrenched, individual efforts even if this approach is the most persistent. Students of religion, philologists, historians and archaeologists must gain an impression of the position and special natural circumstances of a cave at such an altitude on a mountain of Crete, of the reasons for choosing it for worship, by examining it personally. It is safe to say, however, that they are not qualified to study these aspects properly. These, however, are inseparable elements of worship, together with orientation, the position of the constellations in different periods for those who were in the cave at night and certainly the movement of light during the day, once more elements very much related to worship, for which there are certain sources. The study of all these and of yet other subjects, is a work for natural scientists. Therefore, there are many subjects connected with the Idaean Cave which are on the point of being

28 ID., in PraktArchEt (1983), p. 443-444, 488-499, pl. 279-82; ibid. (1986), (in press); in Ergon (1986), p. 139-141, fig. 121-122.

29 I.e. ID., in PraktArchE! (1983), fig. $278 \alpha$. 
examined closely using inter-disciplinary research. And in this instance, it is fortunate that much evidence is preserved in position undamaged by the passage of time. Fortunate, too, are the names of the neighbouring mountain tops, one of which is called Tympanatoras, which alludes to an act of worship, namely the beating of the drums by the Kouretes at the birth of Cretan Zeus.

Rodon 1, Drossia,

J.A. SAKELLARAKIS

GR - 14565 ATHENS 